\title{
CYTOMEGALOVIRUS DISEASE OF THE UPPER GASTROINTESTINAL TRACT IN A PATIENT WITH GRANULOMATOSIS POLYANGIITIS
}

GERMANA RIBEIRO ARAUJO CARNEIRO DE LUCENA (UNIVERSIDADE FEDERAL DE SÃO PAULO, SÃO PAULO, SP, Brasil), DANIEL VIANA DA SILVA E SILVA (UNIVERSIDADE FEDERAL DE SÃO PAULO, SÃO PAULO, SP, Brasil), PRISCILA DIAS CARDOSO RIBEIRO (UNIVERSIDADE FEDERAL DE SÃO PAULO, SÃO PAULO , SP, Brasil), RENAN RODRIGUES NEVES RIBEIRO DO NASCIMENTO (UNIVERSIDADE FEDERAL DE SÃO PAULO , SÃO PAULO , SP, Brasil), IGOR BELTRÃO DUARTE FERNANDES (UNIVERSIDADE FEDERAL DE SÃO PAULO , SÃO PAULO , SP, Brasil), LUÍZA SÁ E RÊGO TUPINAMBÁ (UNIVERSIDADE FEDERAL DE SÃO PAULO, SÃO PAULO, SP, Brasil), MARIANA DAVIM FERREIRA GOMES (UNIVERSIDADE FEDERAL DE SÃO PAULO , SÃO PAULO , SP, Brasil), RAQUEL MITIE KANNO (UNIVERSIDADE FEDERAL DE SÃO PAULO, SÃO PAULO , SP, Brasil), ALEXANDRE LIMA MATOS (UNIVERSIDADE FEDERAL DE SÃO PAULO, SÃO PAULO , SP, Brasil), EDGARD TORRES DOS REIS NETO (UNIVERSIDADE FEDERAL DE SÃO PAULO , SÃO PAULO , SP, Brasil)

\section{BACKGROUND}

Cytomegalovirus (CMV) is an opportunistic infection reported in immunocompromised patients, such as those with rheumatic diseases, which might cause serious complications. Data related to CMV diseases of the upper gastrointestinal tract (CMV-UGT) are limited in patients with reumathologic diseases. We present a rare case of a pacient with granulomatosis with polyangiitis (GPA) who developed a severe CMVUGT that simulated a gastric cancer.

\section{CASE REPORT}

Man, 55-year-old, diagnosed with granulomatosis with polyangiitis since September 2017 due to multiple cranial nerves syndrome, bilateral visual acuity reduction, aseptic meningitis, pulmonary nodule and necrotizing renal vasculitis. In addition, he had a primary immunoglobulin deficiency diagnosed. For GPA's treatment he has tried many approaches that failed and/or caused opportunistic infections. The last of them was a single dose of rituximab on October 2018. In January 2019, he started feeling an intense upper abdominal pain, associated with nausea, involuntary weight loss of $6 \mathrm{~kg}$, night sweats and daily fever, as well as a severe daily headache and unilateral reduced visual acuity. In April 2019, he was admitted for investigation, when he underwent upper digestive endoscopy (EGD), which revealed a large ulcerated and infiltrative lesion from the distal esophagus to the upper body of the stomach. An echoendoscopy was also performed, which showed muscularis propria layer invasion. Considering malignant neoplasia the most probable cause, a chest and abdomen tomography was performed, both without significant alterations. Cranial MRI and paranasal sinus tomography showed no signs of disease activity or metastasis. A biopsy of the lesion was done and revealed the presence of nuclear alterations suggesting viral infection, and immunohistochemical evidenced the presence of CMV. An ophthalmological examination evidenced a retinal detachment, which was associated with the virus infection. Serology for CMV showed a positive IgG 30.09, non-reactive IgM, and PCR quantification of CMV DNA resulted strongly positive with 112980 copies. Thus, he was diagnosed with CMV gastric ulcer and he underwent ganciclovir treatment for 21 days. After the treatment, a new EGD was performed and a complete resolution of the ulcer was achieved. Furthermore, a new quantitative PCR resulted in less 500 copies of the CMV, confirming the resolution of the viral infection. [SEP

\section{CONCLUSION}


In conclusion, though the incidence of CMV-UGT is low, this condition can be a life-threatening complication of rheumatic diseases and its theurapeutics. It is imperative to regard immunosuppressive therapy, as well as as hypogammaglobulinemia, as important risk factors for the development of CMV. 